\title{
Crackers Made of Green Mussel Shells Substitution as High Calcium Snacks
}

\author{
Laili Hidayati, Lailatul Fitria \\ Study Program of Culinary, Faculty of Engineering \\ Universitas Negeri Malang \\ Malang, Indonesia \\ laili.hidayati.ft@um.ac.id
}

\begin{abstract}
This research is experimental research of crackers made of green mussel shells as the substitution in amount of 5\% and $10 \%$ with boiling and steaming methods. The aim of this research is to know physical characteristics (color and texture), calcium content, and organoleptic/predilection test (color, texture, taste). Panelists of this research are 25 untrained panelists in Desa Tambak Rejo, Pantai Sendang Biru. The data are analysed by using ANOVA and DMRT (Duncan Multiple Range Test). The result of crackers colour with green mussel (Perna viridis) shells as the substitution shows means for $L$ (brightness) colour with 40.07 to 36, a+ (reddish) colour with 1.57 to 1.13 , and b+ (yellowish) colour with 5.23 to 4.2. The highest mean of texture is on P3 treatment (boiling method by adding $5 \%$ of green mussel shells' flour) with 23.067. The highest mean of calcium is on P4 treatment (boiling method by adding $10 \%$ of green mussel shells' flour) with 396.81. The rate of panelists' predilection towards colour on $\mathbf{P 2}$ treatment (steaming method by adding $10 \%$ of green mussel shells) is the most liked crackers colour (3.64). The predilection rate towards texture on $\mathbf{P 4}$ treatment (boiling method by adding $5 \%$ of green mussel shells' flour) is the most liked crackers texture (3.99). While the predilection rate towards taste on P4 treatment (boiling method by adding $10 \%$ of green mussel shells' flour) is the most liked crackers taste (3.27).
\end{abstract}

Keywords-green mussel, crackers, calcium

\section{INTRODUCTION}

Green mussel (Perna viridis) is a commodity of a group of shellfish that have been known to the public, in addition to blood cockle (Tegillarca granosa), Chinese pond mussel (Anodonta woodiana), and cockle (Anadara antiquata). Green mussel is one of the marine animals that have long been known as a cheap source of protein, rich in essential amino acids (arginine, leucine, and lysine). Cultivation of mussels is increasingly intensified, as the local market demand increases. This illustrates that the green mussel processing unit activity is increasing. The green mussel processing activity sufficiently generates high solid waste. Recently, the solid waste scallop shell has been only used as wall decoration materials, handicrafts, or even as animal feed mixes. Sewage treatment does not certainly have added value. Therefore, the effort of using the waste for diversified food products of human formulated in the form of flour as a source of natural calcium and as a fortification in a popular product in the society, namely crackers, is necessarily needed (Wahyuni, 2007).

Crackers are made from tapioca dough mixed with flavoring ingredients such as shrimp or fish. Crackers are made by steaming batter before being thinly cut, dried in the sun, and fried in cooking oil that much. Crackers are very popular food, easy way of making, varied colors and flavors, favored by all ages and ethnic groups in Indonesia. However, the crackers product has been recently consumed as snack food that is only for entertaining, having less attention to the nutritional value or quality. The utilization of mussel shells is made into flour which contains calcium and applied as additives in the crackers products. This is expected to increase the added value which is useful for the society. The calcium content of the shells which is made of flour ranges $28.97 \%$ to $39.55 \%$ (Yulianti dalam Rohadi, 2010). Indeed, the calcium is the main substance that the body needs in the formation of bones and teeth (Winarno, 2002).

The purpose of this study is to determine the physical characteristics (color and texture), calcium content, the panelist preference level of the color and texture, and crackers' flavor with green mussel shells' flour as the substitution.

\section{METHODS}

This type of research is experimental research (experimental design). The experiment is conducted to figure out the effect of a treatment. The research uses a completely randomized design (CRD) to test the physical characteristics, the calcium content, and the preference level (color, taste, and texture) of the crackers with the substitution of green mussel shells' flour by using different processing methods. There will be 25 people as the panelists.

The data analysis method used is the analysis of a wide variety of ANOVA, completely randomized factorial method. If the analysis result F-test $>$ F-table shows a real difference, it will proceed with DMRT (Duncan Multiple Range Test). The research design can be seen in Table 1 . 
TABLE I. RESEARCH DESIGN

\begin{tabular}{llcc}
\hline \multirow{2}{*}{ Treatment (T) } & \multicolumn{3}{c}{ Percentage (P) } \\
\cline { 3 - 4 } & & P1 & P2 \\
\hline T1 & T1 P1 & T1 P2 \\
T2 & T2 P1 & T2 P2 \\
\hline
\end{tabular}

Notes:

T1 P1: Steaming method with the addition of green mussel shells' flour 5\%

T1 P2: Steaming method with the addition of green mussel shells' flour $10 \%$

T2 P1: Boiling method with the addition of green mussel shells' flour 5\%

T2 P2: Boiling method with the addition of green mussel shells' flour $10 \%$

The ingredients used in this study are:

- Ingredients for making the shell flour include green mussel shells and $\mathrm{NaOH}$.

- Ingredients for making the crackers include tapioca, green mussel shells' flour, salt, sugar, garlic, and water.

- Chemical analysis

- Calcium: methyl orange, ammonium oxalate, H2SO, $\mathrm{KmnO} 4, \mathrm{NaOH}$, dimethyl sulfoxide, and 8-hydroxy quinoline.

The tools used in making the crackers with the substitution of green mussel shells' flour are scales, thermometers, stainless steel pans, steamers, stoves, basins, pans, spatulas, frying pans, refrigerator, cutting machine, drying cabinet, grinder, and sieve.

TABLE II. CRACKERS RECIPE

\begin{tabular}{|c|c|c|c|c|}
\hline \multirow{2}{*}{ Ingredients } & \multicolumn{2}{|c|}{ Persentage } & \multicolumn{2}{|c|}{ Gram } \\
\hline & $5 \%$ & $10 \%$ & $5 \%$ & $10 \%$ \\
\hline Tapioca & $62 \%$ & $57 \%$ & 620 & 570 \\
\hline $\begin{array}{l}\text { Green mussel shells' } \\
\text { flour }\end{array}$ & $5 \%$ & $10 \%$ & 50 & 100 \\
\hline Salt & $2.7 \%$ & $2.7 \%$ & 27 & 27 \\
\hline Sugar & $1.3 \%$ & $1.3 \%$ & 13 & 13 \\
\hline Garlic & $2 \%$ & $2 \%$ & 20 & 20 \\
\hline Water & $27 \%$ & $27 \%$ & 270 & 270 \\
\hline
\end{tabular}

The steps of making the green mussel shells' flour

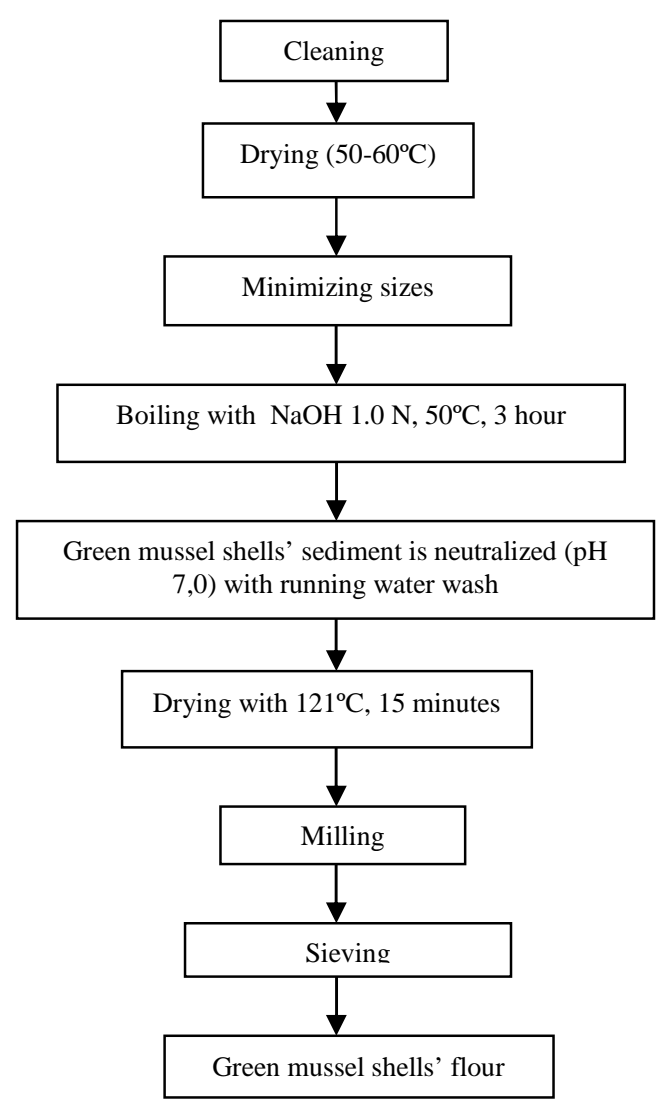

Fig. 1. The Flow Chart of Making the Green Mussel Shells' Flour (Wahyuni, 2007)

The procedure of making crackers with the substitution of green mussel shells' flour is as in Fig. 1. The flow chart of the process in making crackers showed in Fig 2.

\section{RESULTS AND ANALYSIS}

\section{Color's characteristics}

The result of the research and observation showed that the means of the crackers color $\mathrm{L}$, $\mathrm{a}$, and $\mathrm{b}$ with the substitution of green mussel shells' flour in different treatments and different flour percentages were different. The means of the crackers color with the substitution of green mussel shells' flour could be seen in Figure 3. 


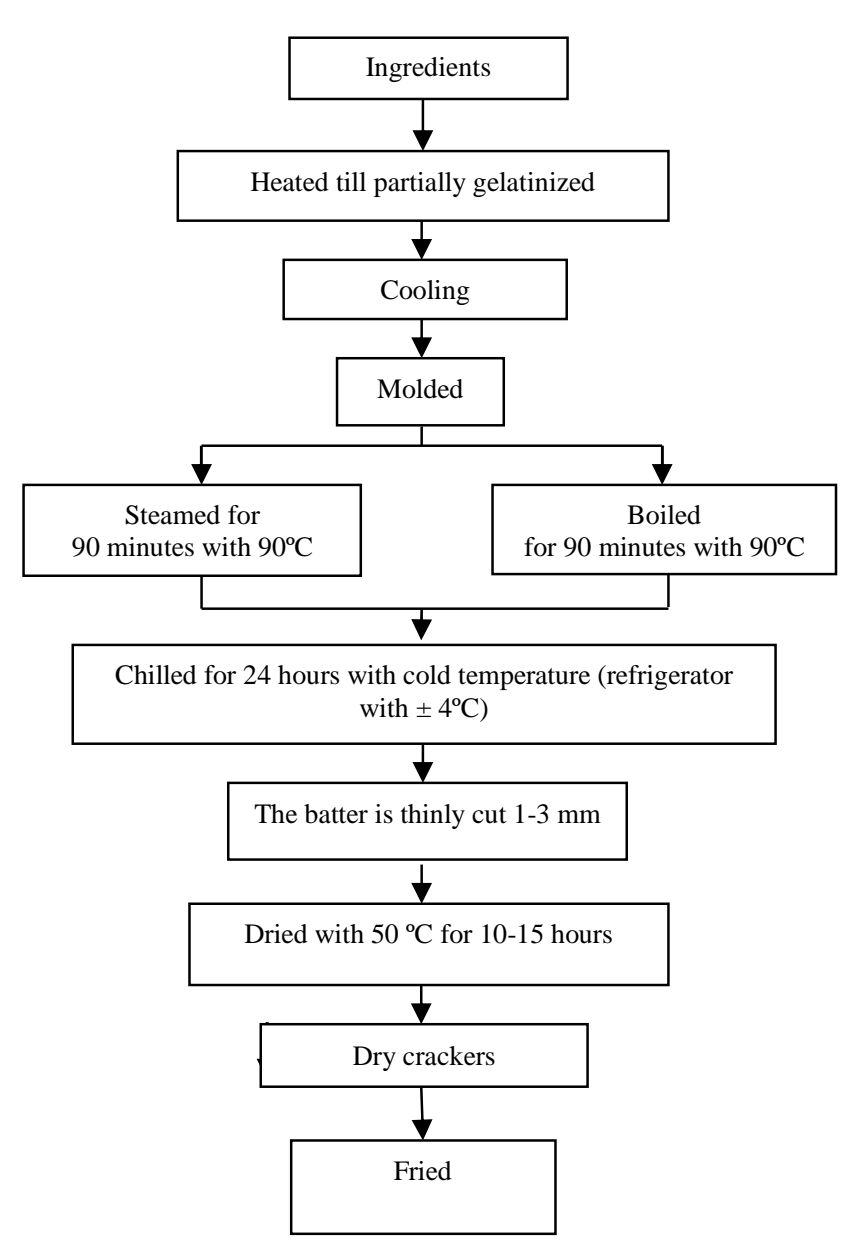

Fig. 2. The flow chart of the process in making crackers

The means of crackers color L, a, and $b$ with the substitution of green mussel shells' flour, steaming and boiling treatments with $5 \%$ dan $10 \%$, were 40.07 to 36 for color $\mathrm{L}$ (brightness), 1.57 to 1.13 for color a+ (reddish), and 5.23 to 4.2 for color $b+$ (yellowish).

The result of the analysis for the crackers color with the substitution of green mussel shells' flour showed that $F_{\text {test }}>$ $F_{\text {table }}$ which included color brightness $3.707>3.33$, redness $30.25>3.33$, and yellowness $50.476>3.33$. Therefore, the data were continually analyzed using variance analysis. The crackers variance analysis percentages (5\% dan 10\%) and different methods (steaming and boiling) gave significant differences $(\alpha=0.05)$ and no significant effects on the crackers color L (brightness), a (reddish), and b (yellowish) with the substitution of green mussel shells' flour. The result of DMRT $(\alpha=0.05)$ on the crackers color $\mathrm{L}, \mathrm{a}$, and $\mathrm{b}$ with the substitution of green mussel shells' flour could be seen in Table 3 .

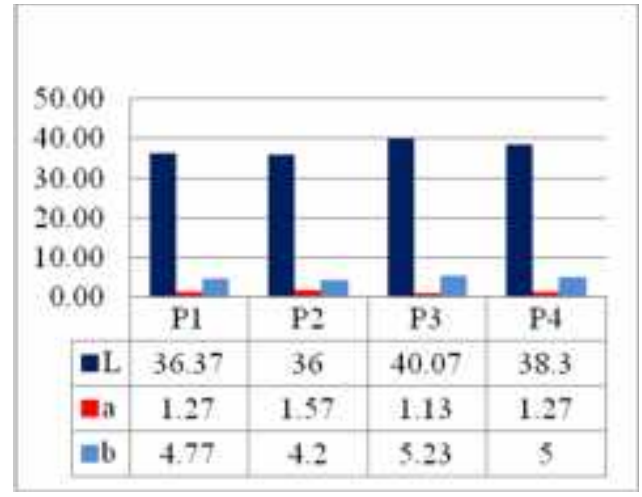

Fig. 3. The Graphic of the Mean of Crackers Color Characteristics with Substitution of Green Mussel Shell' Flour (mg/100g)

Notes

- P1 : Steaming method with the addition of green mussel shells' flour 5\%

- $\mathrm{P} 2$ : Steaming method with the addition of green mussel shells' flour $10 \%$

- P3 : Boiling method with the addition of green mussel shells' flour 5\%

- P4 : Boiling method with the addition of green mussel shells' flour $10 \%$

Table 3 showed the means of crackers color $\mathrm{L}$, $\mathrm{a}$, and $\mathrm{b}$ with the substitution flour of green mussel shells. The means which were accompanied by different notation letters showed that the treatments were significantly different in DMRT $(\alpha=$ $0.05)$, meanwhile the means which were accompanied by the same notation letters showed that there were no significant differences for the treatments in DMRT $(\alpha=0.05)$.

TABLE III. THE MEAN OF CRACKERS COLOR L, A, AND B WITH SUBSTITUTION OF GREEN MUSSELSHELLS' FLOUR

\begin{tabular}{lllcccccc}
\hline \multirow{2}{*}{ Treatment } & \multirow{2}{*}{$\begin{array}{c}\text { Percentage } \\
\end{array}$} & & \multicolumn{3}{c}{ Means } & \multicolumn{4}{c}{ Notation } \\
\cline { 4 - 9 } & $5 \%$ & & $\mathbf{L}$ & $\mathbf{a}$ & $\mathbf{b}$ & $\mathbf{L}$ & $\mathbf{a}$ & $\mathbf{b}$ \\
\hline Steamed & $10 \%$ & 36.37 & 1.27 & 4.77 & $\mathrm{a}$ & $\mathrm{b}$ & $\mathrm{b}$ \\
Steamed & $5 \%$ & 36 & 1.57 & 4.2 & $\mathrm{a}$ & $\mathrm{c}$ & $\mathrm{a}$ \\
Boiled & $10 \%$ & 40.07 & 1.13 & 5.23 & $\mathrm{~b}$ & $\mathrm{a}$ & $\mathrm{d}$ \\
Boiled & & 38.3 & 1.27 & 5 & $\mathrm{ab}$ & $\mathrm{b}$ & $\mathrm{c}$ \\
\hline
\end{tabular}

The result of DMRT $(\alpha=0.05)$ on the color L (brightness) showed that the crackers of green mussel shells' flour substitution 5\% using steaming method were not significantly different from the crackers of green mussel shells' flour substitution $10 \%$ using steaming method. Meanwhile, the crackers of green mussel shells' flour substitution 5\% using boiling method were significantly different from the crackers of green mussel shells' flour substitution 5\% and $10 \%$ using steaming method. Besides, the crackers of green mussel shells' flour substitution $10 \%$ using steaming method were not significantly different from the other green mussel shells' flour substitution. 
The result of DMRT $(\alpha=0.05)$ on color a (reddish) indicated that the crackers of green mussel shells' flour substitution $5 \%$ using steaming method were not significantly different from the crackers of green mussel shells' flour substitution $10 \%$ using boiling method, yet were significantly different from the flour substitution $10 \%$ using steaming method and the flour substitution 5\% using boiling method. Moreover, the crackers of green mussel shells' flour substitution $10 \%$ using steaming method were significantly different from the flour substitution 5\% using boiling method.

The result of DMRT $(\alpha=0.05)$ on color b (yellowish) indicated that all treatments on the crackers of green mussel shells' flour substitution (5\% and $10 \%$, steaming and boiling methods) were significantly different.

According to Desrosier (1988), the foodstuffs which are undergoing the processing and heating can be assumed that they have a real change on their colors. The process of heating, freezing, and drying foods alters the physical and chemical quality. Drying the foodstuff will change the nature of its physical, chemical, and color. The substitution treatment of green mussel shells' flour tends to fade the crackers color. This is assumed that there is natural color affection of the green mussel shells' flour with the high degree of white color $(42.87 \%$, brownish white). Tapioca has neutral taste and light color (Radley, 1976). Besides, it is assumed that the sucrose sugar (glucose and fructose) reacts with the protein in the green mussel shells' flour in which it is called as Maillard reaction (Permana, 2006). This makes the crackers color with the green mussel shells' flour substitution darker and more reddish.

\section{Texture Characteristics}

Results of the research and observation showed that the texture means (hardness) of the crackers with green mussel shells' flour substitution with the treatment and different flour percentage ranged from 19.6 to 23.067 . The texture mean (hardness) of the crackers with green mussel shells' flour substitution with the treatment and different flour percentage can be seen in Table 4 .

TABLE IV. TEXTURE MEAN OF THE CRACKERS WITH GREEN MUSSEL SHELLS' FLOUR SUBSTITUTION (MG/100G)

\begin{tabular}{ccc}
\hline \multirow{2}{*}{ Treatment } & \multicolumn{2}{c}{ Mean } \\
\cline { 2 - 3 } & $\mathbf{5 \%}$ & $\mathbf{1 0 \%}$ \\
\hline Steaming & 21.06 & 19,6 \\
Boiling & 23.067 & 22 \\
\hline
\end{tabular}

The analysis result on the crackers texture with green mussel shells' flour substitution indicated that $\mathrm{F}_{\text {test }}>\mathrm{F}_{\text {table, that }}$ is $22.727>3.33$. Then, it was followed by variance analysis. The variance analysis of the crackers flour substitutions (5\% dan $10 \%$ ) and methods (steaming and boiling) gave significant difference $(\alpha=0.05)$ and no significant difference on the crackers texture with green mussel shells' flour substitutions. The DMRT result $(\alpha=0.05)$ on the crackers texture with green mussel shells' flour substitutions can be seen in Table 5 .
TABLE V. THE TEXTURE MEAN OF THE CRACKERS WITH GREEN MUSSEL SHELLS' SUBSTITUTION

\begin{tabular}{llll}
\hline $\begin{array}{l}\text { Treatment } \\
(\mathbf{T})\end{array}$ & Percentage (P) & Mean & Notation \\
\hline Steamed & $5 \%$ & 21.067 & $\mathrm{~b}$ \\
Steamed & $10 \%$ & 19.6 & $\mathrm{c}$ \\
Boiled & $5 \%$ & 23.067 & $\mathrm{a}$ \\
Boiled & $10 \%$ & 22 & $\mathrm{~b}$ \\
\hline
\end{tabular}

Table 5 showed that the texture means of the crackers with green mussel shells' flour substitution with different notation letters was significantly different on the treatments in DMRT $(\alpha=0.05)$. Meanwhile, if it was with the same notation letters, it indicated no significant difference on the treatments in $\operatorname{DMRT}(\alpha=0.05)$.

The result of the study also indicated that the texture means (hardness) of the crackers substituted by green mussel shells' flour with bigger numbers had more hardness degree than the smaller numbers. Texture is one of the most important factors in crackers products. The different texture of the crackers with green mussel shells' flour substitution was assumed that it had correlation with the process of starch gelatinization in the crackers batter. The substitution of green mussel shells' flour caused decreasing ability of the tapioca starch granules in absorbing the water, so the crackers cavities declined in the frying process and it made the crackers not crispy. The frying process will occur evaporation bounded in the starch gel due to the increasing temperature resulting vapor pressure urging the starch gel, so it causes the development of cavities in the fried crackers (Siaw et al, 1985).

\section{Chemical Characteristics (Calcium Content)}

The result of the research and observation showed that the crackers's calcium content means of the green mussel shells' flour substitution with different treatments and percentages ranged between $352.62 \mathrm{mg} / 100 \mathrm{~g}$ to $396.81 \mathrm{mg} / 100 \mathrm{~g}$. The calcium content mean scores with different treatments and percentages can be seen in Table 6 .

TABLE VI. CRACKERS'S CALCIUM CONTENT MEAN WITH GREEN MUSSEL SHELLS' FLOUR SUBSTITUTION (MG/100G)

\begin{tabular}{ccc}
\hline \multirow{2}{*}{ Treatment } & \multicolumn{2}{c}{ Mean } \\
\cline { 2 - 3 } & $\mathbf{5 \%}$ & $\mathbf{1 0 \%}$ \\
\hline Steaming & $\mathbf{3 5 2 . 6 2}$ & $\mathbf{3 2 6 . 9 4}$ \\
Boiling & $\mathbf{3 8 1 . 7 9}$ & $\mathbf{3 9 6 . 8 1}$ \\
\hline
\end{tabular}

The analysis result on the crackers's calcium content with green mussel shells' flour substitution indicated that $\mathrm{F}_{\text {test }}$ $>\mathrm{F}_{\text {table, }}$, that was $122.808>3.33$. Then, the variance analysis was implemented. The variance analyses (5\% dan 10\%) and different methods (steaming and boiling) gave significant difference $(\alpha=0.05)$ and no significant difference on the crackers texture with green mussel shells' flour substitution. The result of DMRT $(\alpha=0.05)$ on the crackers texture with green mussel shells' flour substitution can be seen in Table 7. 
TABLE VII. CRACKERS'S CALCIUM CONTENT MEAN WITH GREEN MUSSEL SHELLS' FLOUR SUBSTITUTION

\begin{tabular}{cccc}
\hline $\begin{array}{c}\text { Treatment } \\
(\mathbf{T})\end{array}$ & Percentage $(\mathbf{P})$ & Mean & Notation \\
\hline Steamed & $5 \%$ & 352.62 & $\mathrm{a}$ \\
Steamed & $10 \%$ & 362.94 & $\mathrm{~b}$ \\
Boiled & $5 \%$ & 381.79 & $\mathrm{c}$ \\
Boiled & $10 \%$ & 396.81 & $\mathrm{~d}$ \\
\hline
\end{tabular}

Table VII indicated the means scores of the crackers's calcium content with green mussel shells' flour substitution. The means with different notation letters showed that there were significant differences on the treatments in DMRT $(\alpha=$ $0.05)$, while there were no significant differences for the treatments with the same notation letters in DMRT $(\alpha=0.05)$. The drying process which was done on the crackers making with the green mussel shells' flour substitution could increase the calcium content. This is in line with Muchtadi (2010) who states that reducing the water content will increase the concentration of the foodstuff's compounds such as protein, soft carbohydrate, and mineral. However, the vitamins and colors generally becomes damaged or corrupted. The calcium content in the flour with green mussel shells is exist due to the main calcium component in the form of calcium carbonate (CaCO3) belonging to the green mussel shells (Gregoire, 1972).

The Heavy Metals Lead $(\mathrm{Pb})$ Content of the Crackers with Green Mussel Shells' Flour Substitution.

Mussels can survive and be settled as filter feeders (filter). Besides, the mussels are not only absorbing food (plankton), but also anything that is around including the heavy metals in the waters. According to the Food and Drug Administration Department of Health of the Republic of Indonesia (DEPKES $R I$ ), the maximum threshold of lead $(\mathrm{Pb})$ on foodstuff cuisines like mussels (Bivalve mollusks) and sea cucumbers is $1.5 \mathrm{ppm}$ or $\mathrm{mg} / \mathrm{kg}$. The lead coming into marine waters will eventually be found inside the bodies of fish and shrimps or animals that live in marine waters. When the fish are eaten by humans, the lead will be accumulated inside the tissues of the human bodies that are harmful to the health as it causes anemia, nervous system damage, kidney distortion, disruption of the reproduction system, IQ deterioration, and disturbance of the substance absorption done by the bones for growth (Arifin, 2002). It can stimulate premature birth as well (Arisandi, 2004). Therefore, analysis has been conducted to determine the content of lead $(\mathrm{Pb})$ in the crackers with green mussel shells' flour substitution. The result shows that the total score of the means ranges between $0.115 \mathrm{mg} / \mathrm{kg}$ to $0.132 \mathrm{mg} / \mathrm{kg}$. This indicates that the lead content is much lower than the maximum limits set by the Food and Drug Administration Department of Health of the Republic of Indonesia (DEPKES $R I)$.
TABLE VIII. THE MEAN SCORE OF HEDONIC COLOR TEST FOR THE CRACKERS WITH GREEN MUSSEL SHELLS' FLOUR SUBSTITUTION

\begin{tabular}{ccc}
\hline \multirow{2}{*}{ Treatment } & \multicolumn{2}{c}{ Mean } \\
\cline { 2 - 3 } & $\mathbf{5 \%}$ & $\mathbf{1 0 \%}$ \\
\hline Steaming & 2.93 & 3.64 \\
Boiling & 3.52 & 3.16 \\
\hline
\end{tabular}

\section{Hedonic Color Test}

The mean scores of the hedonic color test for the panelist preference level on the crackers colors of the green mussel shells' flour substitution with different treatments and increment percentages of shell flour are obtained as follows.

Based on Table 8 , it could be seen that the means of hedonic color test to the crackers with green mussel shells' flour substitution on the treatments steaming 5\% (2.93), steaming $10 \%$ (3.64), boiling $5 \%$ (3.52), and boiling $10 \%$ (3.16).

The differences of the hedonic color test to the crackers with green mussel shells' flour substitution on the different treatments and percentages can be seen in Table 9.

TABLE IX. ONE-WAY ANALYSIS OF VARIANCE

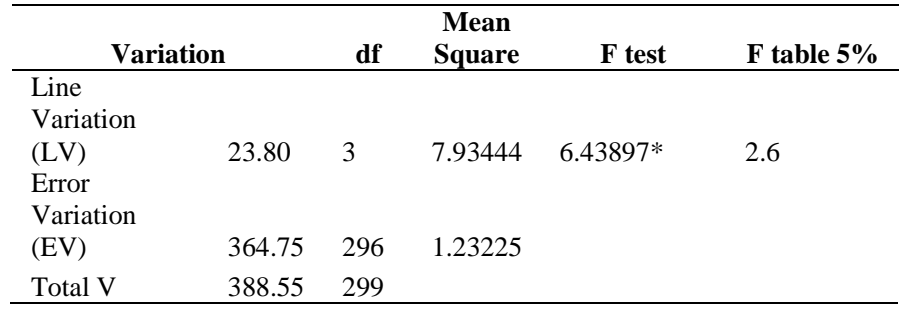

The result of analysis of variance showed a significant difference for the panelists' preference level on the crackers's color with the green mussel shells' flour substitution. This could be seen from the significant level $5 \%$ with the F-test (6.43) > F-table (2.6). Therefore, the analysis was proceeded by DMRT (Duncan's Multiple Range Test) to determine the differences on the panelists' preference level on the crackers's color with the green mussel shells' flour substitution in the different treatments. This can be seen in Table 10 .

TABLE $X$. THE RESULT OF DMRT FOR COLOR HEDONIC

\begin{tabular}{lllll}
\hline df error & & 2 & 3 & 4 \\
\cline { 1 - 3 } 5\% & & 2.77 & 2.92 & 3.02 \\
\hline SSR 5\% & & 0.355058 & 0.374285 & 0.387103 \\
\hline unit & P1 & P2 & P3 & P4 \\
\hline P1 & 0.00 & $0.71^{*}$ & $0.59^{*}$ & 0.23 \\
P2 & & 0.00 & 0.12 & $0.48^{*}$ \\
P3 & & & 0.00 & $0.36^{*}$ \\
P4 & & & 0.00 \\
\hline
\end{tabular}

*: Significantly different in to the significant level of $5 \%$

The different means of color hedonic test to the crackers with green mussel shells' flour substitution between treatment $\mathrm{P} 1$ and $\mathrm{P} 2$ (0.71), treatment P1 and P3 (0.59), treatment P2 and P4 (0.48), treatment P3 and P4 (0.36) indicated significant 
difference. This was because the different means on each treatment were greater than the SSR value 5\%. However, the treatment of P2 and P3 (0.12), treatment P1 and P4 (0.23), showed no significant difference since the different means on each treatment were lesser than the SSR value 5\%. Drying on foodstuff would change its physical characteristics, chemical substances, and colors. The substitution treatment with green mussel shells' flour tended to lower the crackers's color. This was assumedly affected by the natural color of the green mussel shells' flour with the highest degree of white (brownish white).

Color was the first parameter that determines the acceptance level of consumers on a certain product. The research using sight was subjectively significant in the hedonic color test. According to Winarno (2004), determination of the foodstuff quality in general depends on several factors such as flavor, color, texture, nutritional value, and another factor like microbiological characteristics. One of the factors that also determines the quality and color can be used as the indicator of homogeneity and ripeness as well as a way of processing that can be characterized by its homogeny or equal color.

The panelist's preference level on the crackers color with the green mussel shells' flour substitution was affected by the level of brightness, reddish, and yellowish. The different colors would decrease the panelist's preference level on the product. According to Desrosier (1988), the foodstuffs undergoing processing and heating can also have significant change in their colors. The process of heating, frozen, or drying to the food changes its physical and chemical quality. The drying process changes the physical, chemical, and color of the food. The substitution treatment with green mussel shells' flour tended to lower the crackers color. This was assumedly affected by the natural color of the green mussel shells' flour with the highest degree of white (brownish white).

TABLE XI. THE MEAN SCORES OF THE PANELIST'S PREFERENCE LEVEL TO THE CRACKERS TEXTURE WITH GREEN MUSSEL SHELIS' FLOUR SUBSTITUTION

\begin{tabular}{ccc}
\hline \multirow{2}{*}{ Treatment } & \multicolumn{2}{c}{ Mean } \\
\cline { 2 - 3 } & $\mathbf{5 \%}$ & $\mathbf{1 0 \%}$ \\
\hline Steaming & 3.99 & 3.67 \\
Boiling & 3.24 & 3.59 \\
\hline
\end{tabular}

\section{Texture Hedonic Test}

Hedonic test results showing the mean scores of the panelist's preference level to the crackers texture with green mussel shells' flour substitution for the different treatments and flour increment percentages can be seen in Table 11 .

Based on Table XI, the mean scores of the panelist's preference level to the crackers texture with green mussel shells' flour substitution for each treatment are 3.99 for P1, 3.67 for $\mathrm{P} 2,3.4$ for $\mathrm{P} 3$, and 3.9 for $\mathrm{P} 4$.

The difference in texture hedonic test of the crackers with green mussel shells' flour substitution for different treatments and percentages can be seen in Table 12 .
TABLE XII. ONE-WAY ANALYSIS OF VARIANCE

\begin{tabular}{lccccc}
\hline \multicolumn{1}{c}{ Variation } & df & $\begin{array}{c}\text { Mean } \\
\text { Square }\end{array}$ & F test & $\begin{array}{c}\text { F } \\
\text { table } \\
\mathbf{5 \%}\end{array}$ \\
\hline $\begin{array}{l}\text { Line } \\
\text { Variation } \\
(\mathrm{LV})\end{array}$ & 21.16 & 3 & 7.0533 & $7.633031^{*}$ & 2.6 \\
$\begin{array}{l}\text { Error } \\
\text { Variation } \\
(\text { EV) }\end{array}$ & 273.52 & 296 & 0.9240 & & \\
Total V & 294.68 & 299 & & & \\
\hline
\end{tabular}

The result of analysis of variance showed a significant difference on panelist's preference level to the crackers texture with green mussel shells' flour substitution. This could be seen from the level of significant $5 \%$ in which F-test (7.63) > Ftable (2.6). Therefore, the analysis was proceeded by DMRT (Duncan's Multiple Range Test) to determine the differences on panelist's preference level to the crackers texture with green mussel shells' flour substitution with different treatments that could be seen in Table 13 .

TABLE XIII. THE RESULT OF DMRT FOR TEXTURE HEDONIC

\begin{tabular}{lllll}
\hline Error df & & 2 & 3 & 4 \\
\hline $5 \%$ & & 2.77 & 2.92 & 3.02 \\
\hline SSR 5\% & & 0.307467 & 0.324116 & 0.335216 \\
\hline unit & P1 & P2 & P3 & P4 \\
\hline P1 & 0.00 & $0.32^{*}$ & $0.75^{*}$ & $0.40^{*}$ \\
P2 & 0.00 & $0.43^{*}$ & 0.08 \\
P3 & & 0.00 & $0.35^{*}$ \\
P4 & & & 0.00 \\
\hline
\end{tabular}

Notes:

* : Significantly different in to the significant level of 5\%

From the table, it could be analyzed that the mean differences of texture hedonic test on the crackers with green mussel shells' flour substitution for the treatments were as follows: P1 and P2 (0.32), P1 and P3 (0.75), P1 and P4 (0.4), P3 and P2 (0.42), and P4 P3 (0.35). The results were significantly different because the mean difference on the each treatment was greater than the SSR 5\%. However, the mean difference on the crackers with green mussel shells' flour substitution for the treatments P4 and P2 (0.08) indicated no significant difference because the mean difference on the each treatment was lesser than the SSR 5\%. The substitution of green mussel shells' flour caused decreasing ability of the tapioca starch granules in absorbing the water, so the crackers cavities declined in the frying process and it made the crackers not crispy.

Texture is one of the most important factors in the crackers products. The substitution of green mussel shells' flour has decreased ability of the tapioca starch granules in absorbing the water, so the crackers cavities decline in the frying process and it made the crackers not crispy. Indeed, the frying process will occur evaporation bounded in the starch gel due to the increasing temperature resulting vapor pressure urging the starch gel, so it causes the development of cavities in the fried crackers (Siaw et al, 1985). 


\section{Flavor Hedonic Test}

The result of hedonic test showed that the mean scores on panelist's preference level to the crackers flavor with green mussel shells' flour substitution with different treatments and flour increment percentages were as follows.

TABLE XIV. THE MEAN SCORE OF THE PANELIST'S PREFERENCE LEVEL TO THE CRACKERS FLAVOR WITH GREEN MUSSEL SHELLS' FLOUR SUBSTITUTION

\begin{tabular}{ccc}
\hline \multirow{2}{*}{ Treatment } & \multicolumn{2}{c}{ Mean } \\
\cline { 2 - 3 } & $\mathbf{5 \%}$ & $\mathbf{1 0 \%}$ \\
\hline Steaming & 2.93 & 3.64 \\
Boiling & 3.52 & 3.16 \\
\hline
\end{tabular}

Based on Figure 14, the mean scores of the panelist's preference level to the crackers flavor with green mussel shells' flour substitution for each treatment are 2.51 for P1, 3.29 for P2, 3.09 for P3, and 3.27 for P4.

The difference in flavor hedonic test of the crackers with green mussel shells' flour substitution for different treatments and percentages can be seen in Table 15 .

The result of analysis of variance showed a significant difference on panelist's preference level to the crackers flavor with green mussel shells' flour substitution. This could be seen from the level of significant 5\% in which F-test (15.88) $>$ Ftable (2.6). Therefore, the analysis was proceeded by DMRT (Duncan's Multiple Range Test) to determine the differences on panelist's preference level to the crackers flavor with green mussel shells' flour substitution with different treatments that could be seen in Table 16.

TABLE XV. ONE-WAY ANALYSIS OF VARIANCE

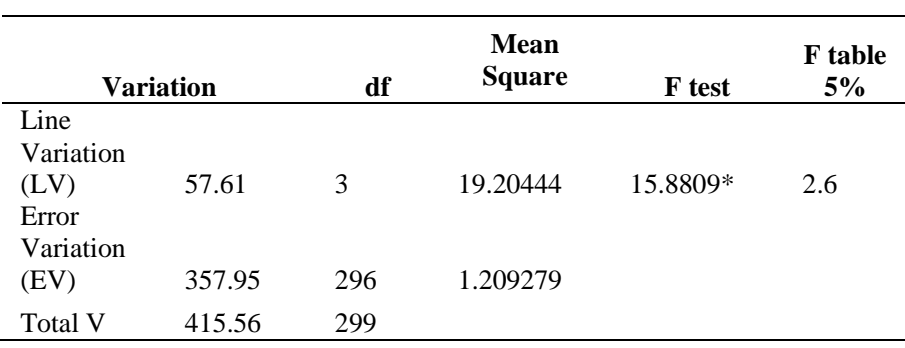

From the table, it could be analyzed that the mean differences of flavor hedonic test on the crackers with green mussel shells' flour substitution for the treatments were as follows: P1 and P2 (0.75), P1 and P3 (0.59), P1 and P4 (0.76). The results were significantly different because the mean difference on the each treatment was greater than the SSR 5\%. However, the mean difference on the crackers with green mussel shells' flour substitution for the treatments P2 and P3 (0.16), P2 and P4 (0.01), P3 and P4 (0.17) indicated no significant difference because the mean difference on the each treatment was lesser than the SSR 5\%. The substitution of green mussel shells' flour influenced the panelist's preference level to the crackers flavor.
TABLE XVI. THE RESULT OF DMRT FOR FLAVOR HEDONIC

\begin{tabular}{lllll}
\hline Error df & & 2 & 3 & 4 \\
\hline 5\% & & 2.77 & 2.92 & 3.02 \\
\hline SSR 5\% & & 0.351732 & 0.370779 & 0.383477 \\
\hline unit & P1 & P2 & P3 & P4 \\
\hline P1 & 0.00 & $0.75^{*}$ & $0.59^{*}$ & $0.76^{*}$ \\
P2 & & 0.00 & 0.16 & 0.01 \\
P3 & & & 0.00 & 0.17 \\
P4 & & & & 0.00 \\
\hline
\end{tabular}

Notes:

* : : Significantly different in to the significant level of 5\%

Flavor plays an important role on the existence of a product. In daily life, consumers are appreciate and are willing to pay more for the delicious food or for what they like, without considering the nutritional composition or other objective characteristics. According to Winarno (2004), flavor is assessed more using the sense of taste. The mean scores of the panelist's preference level to the crackers flavor with green mussel shells' flour substitution showed significant difference on the panelist's preference level in terms of taste.

\section{CONCLUSION}

The result of analysis for crackers color with the substitution of green mussel shells' flour, steaming and boiling treatments with $5 \%$ dan $10 \%$, were 40.07 to 36 for color L (brightness), 1.57 to 1.13 for color a+ (reddish), and 5.23 to 4.2 for color b+ (yellowish).

The results of analysis the texture means (hardness) of the crackers with green mussel shells' flour substitution with the treatment and different flour percentage ranged from 19.6 (steaming method with substitution of green mussel shells' flour 10\%) to 23.067 (boiling method with substitution of green mussel shells' flour 5\%)

The result of analysis on calcium content indicated that the highest mean score was on the treatment P4 (boiling method with substitution of green mussel shells' flour 10\%) with 396.81 and the lowest mean score was on the treatment P1 (steaming method with subtitution of green mussel shells' flour $5 \%$ ) with 352.52 .

The panelist's preference level to the crackers color with green mussel shells' flour substitution on the treatment P2 (steaming method with substitution of green mussel shells' flour $10 \%$ ) was the most liked color (has the highest mean of color organoleptic, that was 3.64). The panelist's preference level to the crackers texture on the treatment P1 (steaming method with substitution $\mathrm{t}$ of green mussel shells' flour 5\%) had the highest mean of texture organoleptic, that was 3.99. The panelist's preference level to the most liked flavor with green mussel shells' flour substitution was on the treatment P4 (boiling method with substitution of green mussel shells' flour $10 \%$ ) with the highest mean of flavor organoleptic, that was 3.27 .

\section{REFERENCES}

Arifin, Z. (2002). Pencemaran di Teluk Jakarta Memprihatikan. Harian Suara Pembaruan. 
Arisandi, P. (2004). Mewaspadai Bahaya Timbal di Surabaya. http://www.ecoton.or id. Diakses pada tanggal 15 januari 2013.

Badan Pengawasan Obat Dan Makanan Republik Indonesia. (2009).

Batas-cemaran-mikroba-dan-kimia, Diakses pada tanggal 15 januari 2013, dari http://staff.unud.ac.id/ semadiantara/wpcontent/uploads/2010/08/Batas-cemaran-mikroba-dankimia.pdf.

Desrosier, N.W. (1988). Teknologi Pengawetan Pangan. Diterjemahkan oleh Mulyohardjo, M. Jakarta: UI Press.

Gregoire C. (1972). Structure of Mollusca Shell. Di dalam: Florkin M, Scheer BT, editor. Chemical Zoology Mollusca. Volume VII. New York: Academic Press. Hlm 45-102

Muchradi. (2010). Ilmu Pengetahuan Bahan Pangan. Bogor. Alfabeta.

Permana, H.( 2006). Optimalisasi Pemanfaatan Cangkang Kerang Hijau (Perna Viridis)dalam pembuatan kerupuk.
(Onlaine), download July 15, 2012, dari: http://anizyn.blogspot.com/2010/06/cangkang-kerupuk.

Radley JA. (1976). Stach Production Technology. London: Upplied Science Pulisher Ltd.

Rohadi, M.B, dkk. (2010). Fungsionalisasi Cangkang Kerang Hijau (Perna Viridis) Sebagai Peningkat Kadar Kalsium Susu Fermentasi. (Onlaine), Download Nov 25, 2011, from: http://anizyn.blogspot.com/2010/06/kalsiumuntuk-tubuh.

Siaw CL, Idrus AZ dan Yean YS. (1985). Intemediate technology for Fish crackeres (kerupuk) production. Journal Food Technology.

Wahyuni M. (2007). Kerupuk Tinggi Kalsium: Nilai Tambah Limbah Cangkang Kerang Hijau Melalui Aplikasi Teknologi Tepat Guna. (Onlaine), (http://www.dkp.go.id/content.php). Diakses pada tanggal 7 November 2011

Winarno, F.G. 2002. Kimia Pangan dan Gizi. Jakarta: Gramedia Pustaka Utama.

Winarno, F.G. 2004. Kimia Pangan dan Gizi. Jakarta: Gramedia Pustaka Utama. 